historical events, implementation of international norms on environmental protection to national legislation.

A particular attention has been paid to the development of the idea of environmental protection in European law in the second half of XX century and the separation within it of European environmental law.

Recently, such important issues as the management of genetically modified organisms, the management of waste and hazardous chemicals, the reduction of harmful emissions into the atmosphere and water pollution have been regulated. This state of legal regulation of environmental relations at the level of international law has a positive impact on the national legislation of the Member States of the European Union and other states that have taken the European direction of development, including Ukraine. One of the important areas of cooperation between the European Union and Ukraine is the joint solution of problems in the field of environmental management and environmental protection.

It has been concluded that the international legal regulation of environmental relations is a system of purposeful actions of subjects of international law, aimed at the rational use of nature and environmental protection in order to preserve it for present and future generations. The green economy is a priority for the European Union.

Keywords: globalization, complex branch of law, ecological law, European law.

УДК $341.645 / 621$

DOI: $10.31733 / 2078-3566-2021-2-20-24$

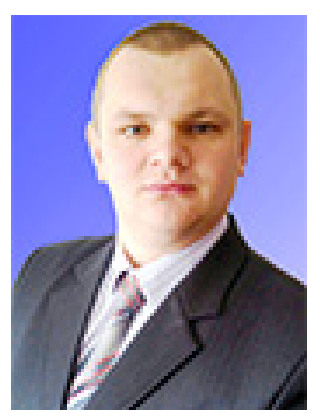

Vitaliy ZAVHORODNII ${ }^{\circ}$

Ph.D in Law, Docent

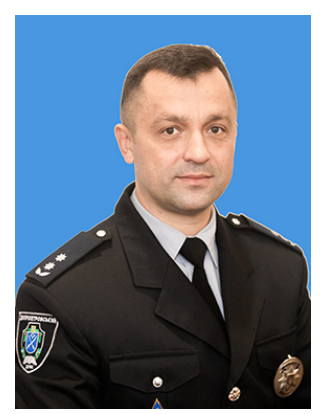

Oleh ZHURAVEL ${ }^{\odot}$

Ph.D in Law

(Dnipropetrovsk State University of Internal Affairs)

\title{
FRIENDLY SETTLEMENT OF DISPUTE IN THE PRACTICE OF THE EUROPEAN COURT OF HUMAN RIGHTS
}

\section{АНОТАЦІЯ}

Віталій Завгородній, Олег Журавель. Дружнє врегулювання спору у практиці свропейського суду з прав людини. З'ясовано існуючі підходи правників до розуміння характерних рис, видів та структури рішень Суду Ради Свропи, що ухвалюються ним 3 підстав дружнього врегулювання спору та обгрунтування на цій основі авторського концепту феноменів декларація про дружнє врегулювання спору та одностороння декларація Уряду. Автором здійснено аналіз та критичне осмислення доктринальних висновків та положень національного законодавства 3 приводу необхідності виокремлення рішень Європейського суду з прав людини, що поряд з постановами Суду Ради Європи, підлягають обов'язковому виконанню державою-учасницею Конвенції про захист прав людини і основоположних свобод.

У ході дослідження встановлено, що Суд Ради Свропи, зважаючи на свою субсидіарну роль, лише пропонує сторонам вичерпати конфлікт, який склався, через можливість укладення двосторонньої угоди, не ухвалюючи при цьому жодних власних правоконстатуючих рішень про дружнє врегулювання спору. Аналіз резолютивної частини рішень Європейського суду з прав людини, які становлять предмет розгляду, свідчить про те, що їх ухвалення має на меті не вирішити справу по суті, чи засвідчити юридичний факт дружнього врегулювання, а вилучити справу з реєстру на підставі такого факту. Резюмується, що рішення Страсбурзького суду, які ухвалюються з підстав дружнього врегулю-

(C) Zavhorodnii V. A., 2021

ORCID iD: https://orcid.org/0000-0002-7489-8170

dnepr-2001@i.ua

(C) Zhuravel O. Ye., 2021

ORCID iD: https://orcid.org/0000-0002-6213-1343

olzhuravel@urk.net 
вання спору між сторонами, не є окремим різновидом постанов Суду Ради Свропи, а отже не мають їх властивостей та не виконуються як такі державою-учасницею Конвенції. У зв'язку з цим сформульовано авторські дефініції понять декларація про дружнє врегулювання спору та одностороння декларація Уряду, які пропонуються включити до положень чинного Закону України "Про виконання рішень та застосування практики Свропейського суду з прав людини".

Ключові слова: Свропейський суд з прав людини, рішення Страсбурзького суду, практика Суду Ради Свропи, декларачія про дружнє врегулювання спору, одностороння декларація Уряду, виконання постанов Свропейського суду з прав людини, міжнародні зобов'язання держави-учасниці Конвенціі.

Relevance of the research. After the recognition of complaints about violation of rights and/or freedoms guaranteed by the European Convention on Human Rights (hereinafter - the Convention), the European Court of Human Rights (hereinafter - the ECtHR) is increasingly offering their services to the conflict parties to reach a friendly settlement of the dispute, which is primarily due to the constant increase in the number of complaints to this international judicial institution, especially from Ukraine.

In this regard, domestic legal science expresses the opinion that there is an independent variety of legal acts of the ECtHR, namely: decisions on friendly settlement of the dispute and decisions approving the terms of the unilateral declaration of the Government. Moreover, this idea was developed in the provisions of Article 1 of the Law of Ukraine "On the fulfillment of decisions and application of practice of the European Court of Human Rights".

However, the legal nature of such decisions of the ECtHR still remains debatable, as does the need for their implementation by the respondent State, similar to the rulings of the ECHR.

Recent publications review. The following domestic and foreign scholars have made a significant contribution to the development of issues concerning the clarifying the peculiarities of the procedures and mechanisms for the friendly settlement of disputes in the ECtHR: T. V. Antsupova, M.O. Baymuratov, O.B. Butkevych, S.K. Burma, O.O. Hrinenko, S.V. Studennikov, A.Ye. Solokhin, B.S. Mukan and others. However, despite the research already made in this area, a number of issues remain unresolved, both related to the understanding of the peculiarities of the decisions of the ECHR, adopted regarding the friendly settlement of the dispute, and the scope of international obligations of a State Party of the Convention arising in this regard.

The article's objective is to clarify the existing lawyers' approaches to understanding the characteristics, types and structure of decisions of the ECtHR, adopted by it for the friendly settlement of disputes and substantiate on this basis the author's concept of phenomena "declaration of friendly settlement" and "unilateral declaration of the Government".

Discussions. From the point of view by S.K. Burma, one of the criteria for distinguishing the types of friendly settlement procedures in the ECHR is the form of the court decision, which should be distinguished: a) friendly settlement decision - in the form of a decision or judgment on the merits; b) decision on removal of the application from the register of cases - in the form of a decision; c) a decision on a friendly settlement - in the form of a report of the Commission or in the form of a decision before 1998. This lawyer emphasizes that the practical side of the implementation of the decisions of the ECtHR on friendly settlement is reduced to the general and individual measures proposed by the ECtHR in its decisions against Ukraine. The greatest difficulties, in the authors' view, arise in the field of eliminating systemic/structural problems in the legal system of Ukraine, identified by the decisions of the Court [1, p. 130, 180-181].

The analysis of the above allows us to state that the author, defining only one criterion for the classification of friendly settlement procedures, does not single out any features of the relevant decisions of the ECtHR. This is confirmed by this scientist's thesis that the respondent state takes measures of general and individual nature to fulfill the decisions of the ECtHR on friendly settlement of the dispute, which is typical for the rulings of the Court of Justice of the ECHR. At the same time we consider ungrounded this scholar's statement that the decision of the ECtHR on the merits is a form of court decision, which is friendly settlement of the dispute, because the use of such a procedure and pursues the goal of exhausting the conflict at the first stage of its detection and avoiding the full procedure of consideration of the case on the merits.

According to M.O. Baimuratov and O.O. Hrinenko, the main criteria of the decisions of the ECtHR on the friendly settlement of disputes in the case against Ukraine should be considered the criteria provided by international law. At the same time, from the point of view of researchers, the criteria established by the practice of the ECtHR are important, in particular reflected in almost all decisions against Ukraine, which describe cases of friendly settlement. These authors include the following: a direct reference to the ECtHR in the operative part of the decision, namely: 39 of the Convention (in decisions of September 2012); b) a statement or establishment of the ECtHR 
in the section of the decision "Law" of the fact that the parties to the case have reached a friendly settlement (in decisions not later than June 2006); c) a statement or establishment of the ECtHR in the section of the decision "Law" that the achieved settlement is based on respect for human rights guaranteed by the Convention and its protocols (in decisions not later than June 2006) [2, p. 15-16].

It follows from the above that the European Court of Human Rights has developed its own approach to the content of decisions taken on the basis of friendly settlement of the dispute. However, apart from the removal of applications from the register of the ECtHR, decisions such as legal acts do not have any effect on a State party to the Convention.

It should be noted that the idea of the existence of ECtHR decisions on friendly settlement of the dispute has its opponents.

For example, O.V. Butkevych emphasizes that Art. 2 of the Law "On Fullfilment of Decisions and Application of the Practice of the ECtHR" declares mandatory on the implementation of the decisions of the ECtHR, and Part 1 of Art. 1 of the same Law includes such decisions as the decision "on friendly settlement in the case against Ukraine".

At the same time, the European Court of Human Rights, as the researcher emphasizes, does not make a decision on friendly settlement of the case (there is a decision of the Court after communication or after the admissibility of removing the application from the list of cases on the basis of friendly settlement by the parties), and the Registry of the Court is involved in this process. Under Article 38 of the Convention, the ECtHR merely places itself at the disposal of the parties concerned in order to ensure a friendly settlement of the dispute, and such negotiations are confidential. In this situation, the issue arises again about what is mandatory in Ukraine, in particular its courts [3, p. 288-289].

A critical understanding of the above statements of lawyers provides grounds for such inferences.

The Declaration on the Friendly Settlement of the Dispute, signed by the State party to the Convention and the complainant due to the latter's allegation of a violation of Convention rights or freedoms, is a voluntary agreement between the two parties concluded on a confidential basis. further consideration of the case by the Court of Justice of the Council of Europe to resolve the conflict that has arisen at the national level without further consideration by the ECtHR of the case on the merits.

Its conclusion is possible provided that a consensus is reached between the parties on the following issues: a) the amount of compensation for violations of human rights or freedoms; b) the obligation of the State to take other specific measures of an individual or general nature in order to restore the complainant's impaired capabilities guaranteed by the Convention; (c) an obligation on the applicant not to lodge any complaint against a State Party to the facts of the application and not to request a retrial.

For example, in a declaration of акшутвдн settlement made in the case of Gongadze v. Ukraine (application no. 34056/02), the Government of Ukraine stated that it was prepared to voluntarily pay Ms Gongadze EUR 100,000) as evidence of a friendly settlement of the case, which is currently before the European Court of Human Rights, and that the Government of Ukraine undertakes to take all necessary measures to continue a thorough investigation into the murder of $\mathrm{Mr}$ Gongadze in order to prosecute all persons guilty of a crime, and will ensure future compliance with the requirements of the provisions of these articles. Despite the outcome of the investigation, the Government undertakes to ensure that all appropriate measures are taken in the future to achieve the outcome of this investigation. Accordingly, the applicant agreed that she would lose the right to make any complaints against Ukraine concerning the facts of the application and undertook not to request that the case be referred to the Grand Chamber under $\S 1$ of Art. 43 of the Convention after the European Court of Justice has ruled in this case [4].

As S.V. Studennikov emphasizes, since January 2019, the European Court of Human Rights is testing a new complaint procedure: before the trial, the applicant and the respondent state will be required to offer a friendly settlement. This is the so-called indisputable (or non-competitive) procedure. The court believes that it will help reduce the time of the case and allow you to get results much faster.

In general, the new procedure is as follows: after examining the complaint (if it is not manifestly inadmissible), the Court will invite the applicant and the Government to agree on a friendly settlement within 12 weeks (send the parties a draft declaration of friendly settlement). The friendly settlement proposal does not establish that a violation has taken place. If the parties agree, the court will exclude the case from the register. The implementation of the friendly agreement will be overseen by the Committee of Ministers of the Council of Europe [5].

For the proper functioning of the above mechanism, the Government of Ukraine has issued a Resolution of 14.08.2019 № 709, the provisions of which stipulate that if the circumstances of the case and previous case law of the European Court give grounds for predicting the Court's finding of a violation of the Convention, the Commissioner concluding an agreement on friendly settlement of the dispute or sending a unilateral declaration and submits this issue to the interdepartmental working group. The decision on the expediency of concluding an agreement on friendly settlement of the dispute, sending a unilateral declaration to the Court and its conditions is made by an interdepartmental working group [6]. 
This suggests that the Court of Justice of the Council of Europe, given its subsidiary role, only offers the parties to settle the conflict through the possibility of concluding a bilateral agreement, without making any own legal decisions on friendly settlement of the dispute. An analysis of the operative part of the judgments of the European Court of Human Rights, which are the subject of consideration, shows that their adoption is not intended to resolve the case on the merits or to certify the legal fact of friendly settlement, but to remove the case from the register on the basis of such a fact.

This position is confirmed by the provisions of Art. 39 of the Convention, part 3 of which states that in the event of a friendly settlement, the European Court of Human Rights removes the case from the register, adopting a decision that contains only a summary of the facts and the solution reached [7].

For example, in the decision of the Strasbourg court of 23.10.2012 on the application № 20440/06, filed by G.K. Apalkova v. Ukraine, the Strasbourg Court states that it received declarations of friendly settlement signed by the parties on 25 August and 10 September 2012, according to which the applicant agreed to waive any further complaints against Ukraine concerning the facts set out in this application. in exchange for the Government's obligation to pay her EUR 1,400 (one thousand four hundred euros) in respect of any pecuniary and non-pecuniary damage, as well as compensation for legal costs to be converted into the national currency of the respondent State at the exchange rate on the day of payments in exchange for the Government's obligation to pay her EUR 1,400 (one thousand four hundred euros) in respect of any pecuniary and non-pecuniary damage, as well as compensation for legal costs to be converted into the national currency of the respondent State at the exchange rate on the day of payment. any taxes. The Court takes note of the fact that the parties have reached a friendly settlement and is convinced that such a settlement is based on respect for the human rights guaranteed by the Convention and the Protocols thereto and finds no grounds for further consideration of the application. On these grounds, the Court unanimously decides to strike the application out of its list of cases in accordance with Article 39 of the Convention [8].

We believe that the legal acts of the European Court of Human Rights are similar in legal nature, which are adopted on the basis of the Government's approval of the terms of the unilateral declaration, which is interpreted by the Court as a friendly settlement by the parties.

Thus, in the judgment of the Court of Justice of the Council of Europe of 18 December 2012 on application № 7635/07 filed by GF Buryak v. Ukraine, the Court noted that on 13 February 2012 and 29 March 2012 it had received a unilateral Government declaration and a letter from the applicant, in which he accepted the terms of this declaration, according to which the applicant agreed to waive any further complaints against Ukraine concerning the facts set out in this application in exchange for the Government's obligation to pay him 100,000 (one hundred thousand) Ukrainian hryvnias of any material and moral damage, as well as compensation for court costs, which must be exempt from any taxes that may be charged. The court takes into account the fact that the parties have reached a friendly settlement. The Court is convinced that such a settlement is based on respect for the human rights guaranteed by the Convention and its protocols and finds no basis for further consideration of the application. On these grounds, the Court unanimously decides to remove the application from the register of cases in accordance with Art. 39 of the Convention [9].

Conclusions. All the above suggests that the examined legal acts of the Strasbourg Court, adopted on the basis of friendly settlement of the dispute between the parties, do not constitute a separate type of judgments of the Court of Justice of the Council of Europe and therefore do not have their properties and are not enforced as such Convention. In the case of declarations of friendly settlement or approval of the terms of a unilateral declaration by the Government, it is correct to speak only of the proper fulfillment by the parties of their obligations under such friendly agreements and of the existence of ancillary nature of decisions of the ECtHR the removal of applications from the register on these grounds..

In view of this fact, Article 2 of the Law of Ukraine "On Fullfilment of Decisions and Application of the Practice of the European Court of Human Rights" needs to be amended, to which should be added regulatory requirements dispute or approval of a unilateral declaration.

At the same time, the provisions of Article 1 of the above-mentioned legal act must be supplemented by the following provisions: 1) a declaration of friendly settlement of a dispute is a voluntary agreement concluded on a confidential basis between the complainant and the state in order to end a conflict that has arisen at the national level in connection with the latter's violation of convention and / or human rights, without further consideration by the European Court of human rights of cases on the merits; 2) a unilateral declaration by the Government is an act by which the Representation Body, in agreement with an interagency working group, proposes conditions for a friendly settlement of a conflict between the complainant and the State at the national level related to the latter's violation of Convention further consideration by the European Court of Human Rights on the merits. 


\section{References}

1. Бурма С. К. Міжнародно-правова характеристика інституту дружнього врегулювання в Європейському суді з прав людини: дис. ... канд. юрид. наук: 12.00.11 / НУ "ОЮА". Одеса, 2015. 231 с.

2. Баймуратов М. О., Гріненко О. О. Рішення Європейського суду з прав людини щодо дружнього врегулювання у справах проти України: проблеми теорії та практики. Журнал східноєвропейського права. 2018. № 49. С. 4-20.

3. Буткевич О. В. Чи є рішення Європейського Суду з прав людини обов'язковими для України, як цього вимагає закон? Правове забезпечення ефективного виконання рішень $і$ застосування практики Європейського суду з прав людини: зб. наук. статей Міжнар. наук.-практ. конф. (Одеса, 15 верес. 2012 р.) / за ред. С.В. Ківалова; НУ «ОЮА». Одеса: Фенікс, 2012. С. 279-293.

4. Декларація про дружнє врегулювання у справі «Гонгадзе проти України» (заява № 34056/02). URL : https://www.kmu.gov.ua/npas/17371955.

5. Студенников С. ЕСПЧ уже применяет процедуру дружественного урегулирования споров. Судебно-юридическая газета. Публикации. 6 декабря 2019 г. URL: https://sud.ua/ru/news/ publication/156257-espch-uzhe-primenyaet-protseduru-druzhestvennogo-uregulirovaniya-sporov.

6. Про внесення змін до постанов Кабінету Міністрів України від 29 квітня 2004 р. № 553 і від 31 травня 2006 р. № 784: постанова Кабінету Міністрів України від 14 серпня 2019 р. № 709. URL: https://www.kmu.gov.ua/npas/pro-vnesennya-zmin-do-postanov-kabinetu-ministriv-ukrayini-vid-29-kvitnya2004-r-553-i-vid-31-travnya-2006-r-784-s140819.

7. Конвенція про захист прав людини і основоположних свобод від 4 листопада 1950 року. URL : https://zakon.rada.gov.ua/laws/show/995 004.

8. Рішення Європейського суду з прав людини від 23 жовтня 2012 року (заява № 20440/06, поданою Галиною Куртівною Апальковою проти України). URL: http://old.minjust.gov.ua/43258.

9. Рішення Європейського суду з прав людини від 18 грудня 2012 року (Заява № 7635/07, подана Григорієм Федоровичем Буряком проти України). URL: http://old.minjust.gov.ua/43258.

Надійшла до редакиії 30.03.2021

1. Burma S. K. (2015) Mizhnarodno-pravova kharakterystyka instytutu druzhn'oho vrehulyuvannya v Yevropeys'komu sudi z prav lyudyny [International legal characteristics of the institution of friendly settlement in the European Court of Human Rights] : dys. ... kand. yuryd. Nauk : 12.00.11 / NU "OYuA". Odesa. 231 p. [in Ukr.].

2. Baymuratov M. O., Hrinenko O. O. (2018) Rishennya Yevropeys'koho sudu z prav lyudyny shchodo druzhn'oho vrehulyuvannya u spravakh proty Ukrayiny: problemy teoriyi ta praktyky [International legal characteristics of the institution of amicable settlement in the European Court of Human Rights]. Zhurnal skhidnoyevropeys'koho prava, no 49, pp. 4-20 [in Ukr.].

3. Butkevych O. V. (2012) Chy ye rishennya Yevropeys'koho Sudu z prav lyudyny obov"yazkovymy dlya Ukrayiny, yak ts'oho vymahaye zakon? [Are the rulings of the European Court of Human Rights binding on Ukraine, as required by law?] Pravove zabezpechennya efektyvnoho vykonannya rishen' $i$ zastosuvannya praktyky Yevropeys'koho sudu z prav lyudyny: zb. nauk. statey Mizhnar. nauk.-prakt. konf., Odesa, 15 veresnya 2012 r. / za red. S. V. Kivalova ; NU «OYuA». Odesa : Feniks, pp. 279-293 [in Ukr.].

4. Deklaratsiya pro druzhnye vrehulyuvannya u spravi «Honhadze proty Ukrayiny» (zayava № 34056/02) [Declaration on amicable settlement in Gongadze v. Ukraine (application no. 34056/02)] URL : https://www.kmu.gov.ua/npas/17371955 [in Ukr.].

5. Studennykov, S. YeSPCh uzhe primenyaet protseduru druzhestvennogo uregulirovaniya sporov [The ECtHR already applies the procedure of amicable settlement of disputes]. Sudebno-yuridicheskaya gazeta. Publykatsyi. 6 dekabrya 2019 h. URL : https://sud.ua/ru/news/publication/156257-espch-uzhe-primenyaetprotseduru-druzhestvennogo-uregulirovaniya-sporov [in Russ.]

6. Pro vnesennya zmin do postanov Kabinetu Ministriv Ukrayiny vid 29 kvitnya 2004 r. № 553 i vid 31 travnya 2006 r. № 784 [On amendments to the resolutions of the Cabinet of Ministers of Ukraine of April 29 , 2004 № 553 and of May 31, 2006 № 784] : postanova Kabinetu Ministriv Ukrayiny vid 14 serpnya 2019 r. № 709. URL : https://www.kmu.gov.ua/npas/pro-vnesennya-zmin-do-postanov-kabinetu-ministriv-ukrayini-vid29-kvitnya-2004-r-553-i-vid-31-travnya-2006-r-784-s140819. [in Ukr.].

7. Konventsiya pro zakhyst prav lyudyny i osnovopolozhnykh svobod vid 4 lystopada 1950 roku [Convention for the Protection of Human Rights and Fundamental Freedoms of 4 November 1950]. URL : https://zakon.rada.gov.ua/laws/show/995 004 [in Ukr.].

8. Rishennya Yevropeys'koho sud̄u z prav lyudyny vid 23 zhovtnya 2012 roku (zayava № 20440/06, podana Halynoyu Kurtivnoyu Apal'kovoyu proty Ukrayiny) [Judgment of the European Court of Human Rights of 23 October 2012 (application no. 20440/06, filed by Halyna Kurtivna Apalkova v. Ukraine)]. URL : http://old.minjust.gov.ua/43258 [in Ukr.].

9. Rishennya Yevropeys'koho sudu z prav lyudyny vid 18 hrudnya 2012 roku (Zayava № 7635/07, podana Hryhoriyem Fedorovychem Buryakom proty Ukrayiny) [Judgment of the European Court of Human Rights of 18 December 2012 (Application № 7635/07, filed by Hryhoriy Fedorovych Buryak v. Ukraine)]. URL : http://old.minjust.gov.ua/43258 [in Ukr.].

\section{ABSTRACT}

The existing approaches of lawyers to understanding the characteristics, types and structure of decisions of the Court of Justice of the Council of Europe, adopted by it on the basis of amicable settlement of disputes and substantiation on this basis of the author's concept of phenomena declaration of amicable settlement and unilateral declaration of the Government. The author analyzes and critically comprehends the doctrinal conclusions and provisions of national legislation on the need to separate the decisions of the European Court of Human Rights, which, along with the rulings of the Court of Justice, are subject to mandatory implementation by the State party to the Convention for the Protection of Human Rights and Fundamental Freedoms.

Keywords: European Court of Human Rights, decisions of the ECtHR, case law of the Court of Justice of the Council of Europe, declaration of friendly settlement of the dispute, unilateral declaration of the Government, implementation of the ECtHR, international obligations of the State party. 